\title{
STRATEGI PENYEDIAAN RTH MELALUI PENINGKATAN PERAN SERTA MASYARAKAT DI PEMUKIMAN KAWASAN INDUSTRI KOTA
}

\author{
Desyrijanti A \\ Universitas Krisnadwipayana, Program Pascasarjana \\ Magister Teknik Kajian Pembangunan Perkotaan dan Wilayah \\ desyrijanti@gmail.com
}

\begin{abstract}
High population growth in urban industrial estate housing causes the need for space to be built large due to reduced availability of green space due to limited land. There is potential for the provision of green open space but is controlled by the community, there is a policy but it is not yet effective, there is participation but it is not optimal. The purpose of this study is to prove the hypothesis and develop several strategies that are effective in providing green open space through increasing community participation in urban industrial estate housing. The method used for hypothesis testing is policy analysis using AHP and community participation analysis using SPSS. The availability of existing green open space is carried out using image map analysis and to calculate green space requirements and the potential for green open space using quantitative calculations. As for developing a strategy for providing open green space through community participation in urban industrial estate housing using a SWOT analysis. The results of this study prove that the strategy exists but has not been effective, participation is there but not optimal, RTH needs have been met but the proportion is not yet in accordance with the provisions (20\% public, $10 \%$ private), the potential for providing green open space is in industrial estates rather than industrial estate housing. Strategies for building green open space by (a) Physical: optimization of residential land by means of a vertical garden and roof garden; (b) Social: increasing community participation by means of socialization, communication, assistance, training and provision of tree seeds; (c) Economy: provision of funds for program implementation and optimization of CSR; (d) Institutional: institutional strengthening by submitting proposals through musrenbang, establishing community-based mobilization, maintenance and monitoring cadres.
\end{abstract}

Key Words: Green Open Space, Community Participation, Housing in Urban Industry Area

\begin{abstract}
Abstrak : Pertumbuhan penduduk yang tinggi di pemukiman kawasan industri kota menyebabkan kebutuhan ruang terbangun besar akibatnya ketersediaan RTH berkurang karena lahan terbatas. Ada potensi penyediaan RTH tetapi dikuasai masyarakat, ada kebijakan tapi belum efektif, ada peranserta tapi belum optimal. Tujuan dari penelitian ini untuk membuktikan hipotesa dan menyusun strategi yang efektif penyediaan RTH melalui peningkatan peran serta masyarakat di pemukiman kawasan industri kota. Metode yang digunakankan untuk uji hipotesa adalah analisis kebijakan dengan menggunakan AHP dan analisis peran serta masyarakat menggunakan SPSS. Untuk ketersediaan RTH eksisting dilakukan dengan menggunakan analisis peta citra dan untuk menghitung kebutuhan RTH serta potensi RTH menggunakan perhitungan kuantitatif. Adapun untuk menyusun strategi penyediaan RTH melalui peranserta masyarakat di pemukiman kawasan industri kota menggunakan analisis SWOT. Hasil penelitian ini terbukti bahwa strategi ada tetapi belum efektif, peranserta ada tetapi belum optimal, kebutuhan RTH sudah terpenuhi tetapi proporsinya belum sesuai ketentuan ( $20 \%$ publik, $10 \%$ privat), potensi terbesar penyediaan RTH ada di kawasan industri bukan di pemukiman kawasan industri. Strategi pembangunan RTH dengan cara (a) Fisik: optimalisasi lahan pemukiman dengan cara vertical garden dan roof garden; (b) Sosial: peningkatan peranserta masyarakat dengan cara sosialisasi, komunikasi, pendampingan, pelatihan dan pemberian bibit pohon; (c) Ekonomi: penyediaan dana untuk pelaksanaan program dan optimalisasi CSR; (d) Kelembagaan: penguatan kelembagaan dengan cara penyampaian usulan lewat musrenbang, menetapkan kader penggerak, pemeliharaan dan pemantauan berbasis masyarakat.
\end{abstract}

Kata Kunci : RTH, Peranserta Masyarakat, Pemukiman Kawasan Industri Kota 


\section{PENDAHULUAN}

Pertumbuhan penduduk yang tinggi di perkotaan terutama di pemukiman kawasan industri kota menyebabkan kebutuhan akan ruang terbangun meningkat, akibatnya ketersediaan RTH berkurang dan kualitas lingkungan menurun. Selain itu, ketersediaan lahan untuk RTH tidak ada atau terbatas. Potensi penggunaan lahan perkotaan ada, tetapi sebagian besar lahan tersebut dikuasai oleh masyarakat. Kebijakan dan strategi penyediaan RTH sudah ada tetapi belum efektif, disisi lain masyarakat memiliki peran yang cukup strategis dalam meningkatkan penyediaan $\mathrm{RTH}$, tetapi perannya masih belum optimal. Untuk itu perlu mengetahui faktor-faktor yang menjadi kendala dalam pelaksanaannya dan menyusun strategi peningkatan penyediaan RTH melalui peranserta masyarakat di pemukiman kawasan industri kota.

\section{METODOLOGI}

Penelitian ini bertujuan untuk membuktikan hipotesa dan menyusun strategi yang lebih efektif untuk meningkatkan penyediaan RTH melalui peranserta masyarakat di pemukiman kawasan industri kota.

Lokasi penelitian dilakukan dilakukan di

Kota Tangerang karena Kota Tangerang merupakan salah satu metropolitan dan juga kota industri yang ada di Indonesia dengan tingkat kepadatan pemukiman dan penduduk yang tinggi. Salah satu lokasi industri yang paling banyak dan besar industrinya serta paling banyak pemukimannya di Kota Tangerang adalah Kecamatan Jatiuwung.

Untuk melakukan penelitian ini ada 4 (empat) metoda analisis yang digunakan, yaitu: (1) analisis kebijakan dengan menggunakan AHP untuk uji hipotesa terkait belum efektifnya strategi penyediaan RTH melalui peranserta masyarakat di pemukiman kawasan industri kota; (2) analisis peranserta masyarakat dengan menggunakan SPSS untuk uji peranserta masyarakat dalam penyediaan RTH di pemukiman kawasan industri kota; (3) analisis RTH eksisting untuk mengetahui sebaran dan luasan RTH yang ada saat ini, analisis kebutuhan untuk mengetahui berapa besar kebutuhan RTH di kecamatan tersebut, analisis potensi untuk mengetahui berapa besar potensi yang ada untuk meningkatkan RTH melalui peranserta masyarakat di pemukiman kawasan industri; (4) analisis SWOT untuk menyusun strategi yang efektif peningkatan penyediaan RTH melalui peranserta masyarakat di pemukiman kawasan industri.

Responden untuk AHP berjumlah 20 orang terdiri dari Bappeda, Dinas PU dan Tata Ruang, Dinas Lingkungan Hidup dan Dinas Partiwisata dan Pertamanan. Adapun untuk SPSS responden berjumlah 120 orang tersebar di lokasi pemukiman yang ada di 6 kelurahan di Kecamatan Jatiuwung.

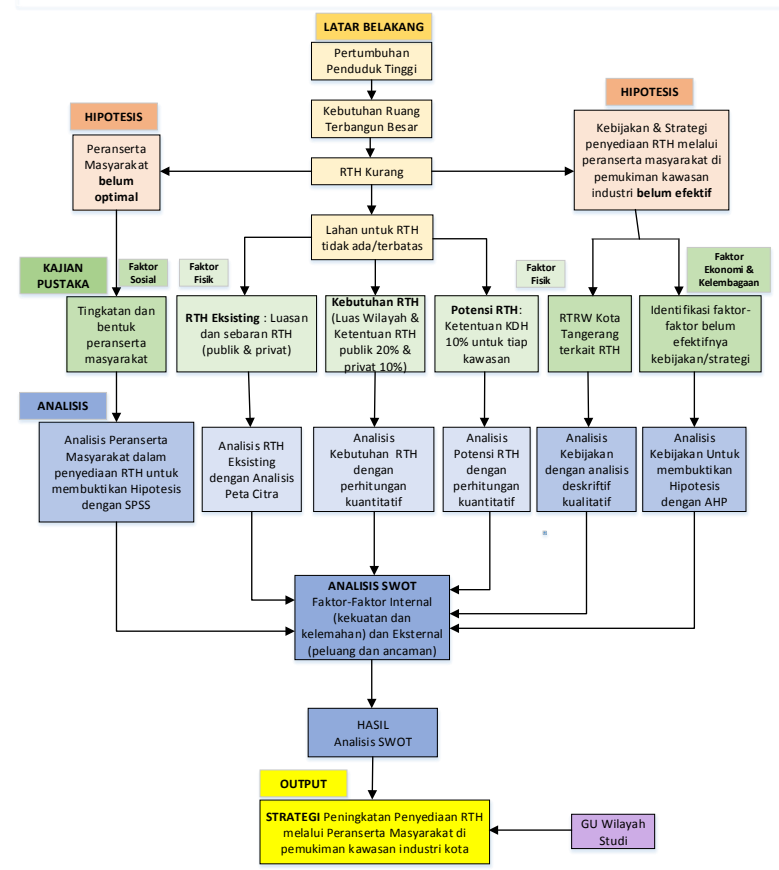

Diagram 1. Kerangka Pemikiran

\section{GAMBARAN UMUM LOKASI}

Kota Tangerang memiliki luas $\pm 184,24$ km2 dan sebagai pintu gerbang Indonesia, merupakan kota metropolitan dan berbatasan langsung dengan Ibukota Jakarta. Kota Tangerang dijuluki kota seribu industri, memiliki peran penting sebagai penyangga Ibukota Jakarta. RTH Kota Tangerang saat ini seluas 333.707,4 Ha atau sekitar 19,84\% dari luas wilayah Kota Tangerang. Luas tersebut terdiri dari $190.878 \mathrm{Ha}$ atau $11,6 \%$ RTH Publik dan 142.829,4 Ha atau $8,68 \%$ RTH Privat.

Lokasi penelitian ada di Kecamatan Jatiuwung. Jatiuwung merupakan salah satu kecamatan yang ditetapkan sebagai kawasan indsutri di Kota Tangerang. Kecamatan Jatiuwung terdiri dari 6 kelurahan untuk jelasnya dapat dilihat pada gambar. 

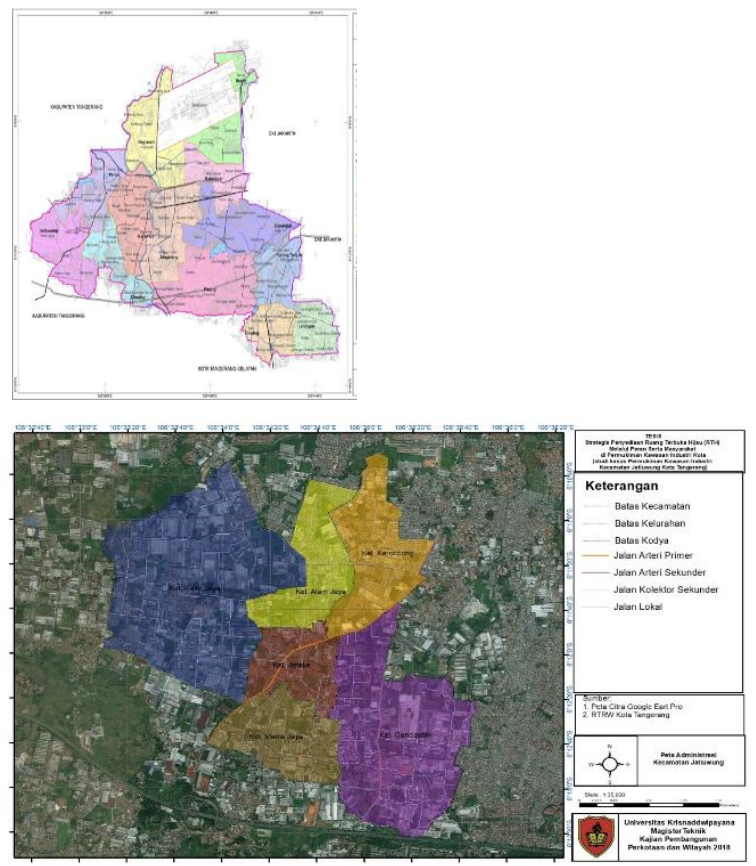

Gambar 1. Lokasi Penelitian

Luas Kecamatan Jatiuwung adalah 14,37 $\mathrm{km} 2$ atau hanya $7,79 \%$ dari total luas Kota Tangerang. Kelurahan yang terluas adalah Kel. Pasir Jaya dan Kel, Gandasari. Adapun jumlah penduduk pada Tahun 2017 sebanyak 124.066 jiwa dengan jumlah penduduk terbanyak di Kel. Gandasari dan Kel. Manis Jaya. Kepadatan penduduk rata-rata di Kec. Jatiuwung adalah $8.634 \mathrm{jiwa} / \mathrm{km} 2$ dengan penduduk terpadat di Kel. Alam Jaya dan Kel. Manis Jaya. Untuk jelasnya dapat dilihat tabel berikut ini.

Tabel 1. Luas dan Jumlah Penduduk Kec. Jatiuwung

\begin{tabular}{|l|r|r|r|}
\hline Kelurahan & $\begin{array}{r}\text { Luas } \\
(\text { Km2) }\end{array}$ & $\begin{array}{c}\text { Jumlah } \\
\text { Penduduk }\end{array}$ & $\begin{array}{c}\text { Kepadatan } \\
\text { Penduduk/ } \\
\text { km2 }\end{array}$ \\
\hline Manis Jaya & 1,60 & 20.560 & 12.850 \\
\hline Jatake & 1,40 & 16.515 & 11.796 \\
\hline Gandasari & 2,90 & 31.373 & 10.818 \\
\hline Keroncong & 1,93 & 19.865 & 10.293 \\
\hline Alam Jaya & 1,42 & 18.656 & 13.138 \\
\hline Pasir Jaya & 5,30 & 17.097 & 3.226 \\
\hline Jumlah & 14,37 & 124.066 & 8.634 \\
\hline
\end{tabular}

Sumber: BPS Kota Tangerang, 2018

Sektor industri pengolahan merupakan sektor yang dominan dalam membentuk perekonomian di Kota Tangerang. Persebaran industri pengolahan paling banyak di Kec. Jatiuwung. Pada Tahun 2017 terdapat 460 perusahaan industri sebagian besar atau 430 adalah industri skala besar/sedang. Kelurahan Gandasari merupakan kelurahan yang paling banyak industrinya yaitu 170 perusahaan industri. Adapun jenis industri yang ada di Kec. Jatiuwung sangat beragam mulai dari industri ban, plastic, manufaktur (metalurgi, teknik, bahan kimia, dan hi-tech).

Pemukiman menyebar merata di seluruh kelurahan dan mengelompok pada titik-titik tertentu di lokasi kawasan industri. Jenis pemukiman ada dua macam, yaitu pemukiman terencana (real estate) dan pemukiman tidak terencana (perkampungan). Sebagian besar pemukiman kepadatannya tinggi dan hanya sebagian kecil saja yang kepadatannya rendah. Umumnya kepadatan tinggi ada di pemukiman tidak terencana atau pemukiman terencana untuk MBR. Kepadatan tinggi yang dimaksud disini adalah antar rumah satu dengan rumah lainnya tidak ada jarak, dindingnya saling menempel, jalannya kecil, luas tanahnya tidak besar antara 50m2-100m2 Pemanfaatan KDB 100\% artinya tidak ada lagi lahan untuk KDH.

Setiap kelurahan yang ada di Kec. Jatiuwung terdapat kawasan industri. Kawasan industri tersebut sebagian besar berbatasan langsung dengan kawasan pemukiman. Sebagian ada buffer zone antara industri dengan industri atau industri dengan pemukiman, tetapi ada juga yang tidak ada green belt. Kawasan hijau yang ada di Kecamatan Jatiuwung berada di sekitar industri. Lahan hijau yang ada terdapat di dalam areal pabrik umumnya tidak terkelola dengan baik. Lahan-lahan terbuka sebagian besar merupakan bagian dari lokasi pabrik ataupun kavling-kavling pabrik yang belum terbangun. Lahan ini umumnya dibiarkan begitu saja sehingga ditumbuhi alang-alang dan semak belukar.

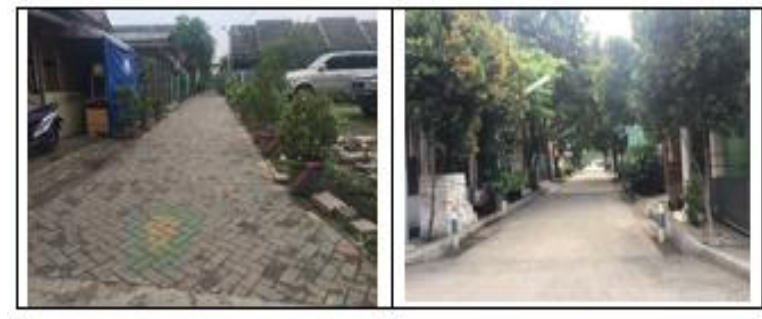

Gambar 2. Kondisi RTH di Pemukiman

\section{ANALISIS DAN HASIL}

\section{A. Analisis Kebijakan}

Uji Hipotesis menggunakan AHP terbukti bahwa strategi penyediaan RTH melalui 
peranserta masyarakat sudah ada, faktor penyebab belum efektif: (1) Fisik (lahan), (2) Ekonomi (dana); (3) Sosial (partisipasi) dan (4) Kelembagaan (sosialisasi/ komunikasi). Untuk jelasnya dapat dilihat pada diagram berikut.

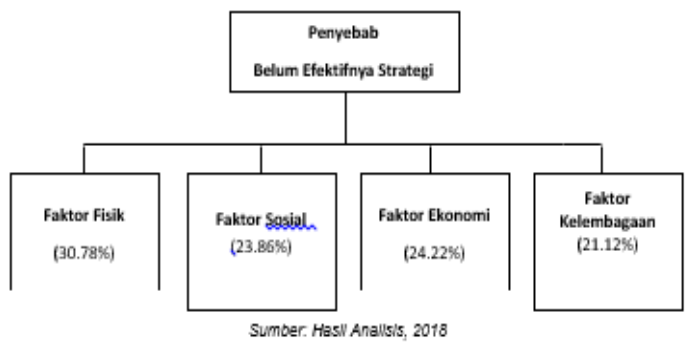

Diagram 2. Diagram Penyebab Belum Efektifnya Strategi

Kebijakan/strategi yang prioritas adalah : (1) Aspek SD (lahan); (2) Aspek komunikasi/sosialisasi; (3) Aspek Disposisi (komitmen); dan (4) Aspek Struktur Birokrasi (kerjasama). Untuk jelasnya dapat dilihat pada diagram dan tabel berikut.

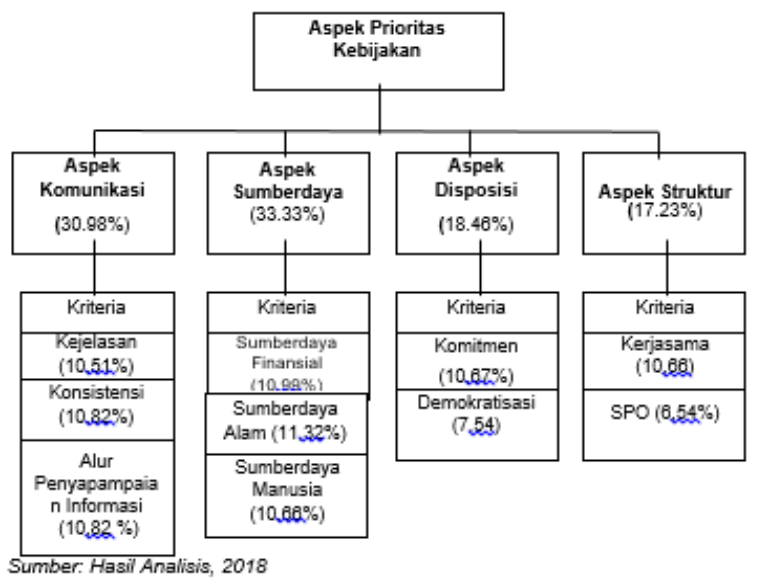

Diagram 2. Aspek Prioritas Kebijakan

Tabel 2. Bobot Kriteria Stategi Penyediaan RTH

\begin{tabular}{|c|c|c|}
\hline Strategi Kebijakan Pengembangan RTH & $\begin{array}{l}\text { Bobot } \\
\text { Final }\end{array}$ & Rangking \\
\hline Sumberdaya Alam (ketersedian lahan) & $11,32 \%$ & 1 \\
\hline Sumberdaya Finansial(Dana) & Tण,gg\% & 2 \\
\hline Aur Penyampalan Informasl & $70,82 \%$ & 3 \\
\hline Konsistens| & $10,82 \%$ & 4 \\
\hline Komitimen & $70,6 / \%$ & 5 \\
\hline Sumberdaya Ivanusia & $10,00 \%$ & ठ \\
\hline Kepasama & $10,00 \%$ & 7 \\
\hline Kejelasan & $10,51 \%$ & 8 \\
\hline Uemokratisas! & $7,54 \%$ & y \\
\hline SUP & $8,54 \%$ & 70 \\
\hline
\end{tabular}

\section{B. Analisis RTH}

\section{Analisis RTH Eksisting}

RTH Publik ada 3 lokasi, sebarannya tidak merata dan hanya 1 lokasi yang dikelola pemda.RTH Privat banyak dan tersebar merata tetapi RTH tersebut merupakan bagian dari lahan industri yang belum dibangun. Untuk jelasnya dapat dilihat pada gambar berikut.

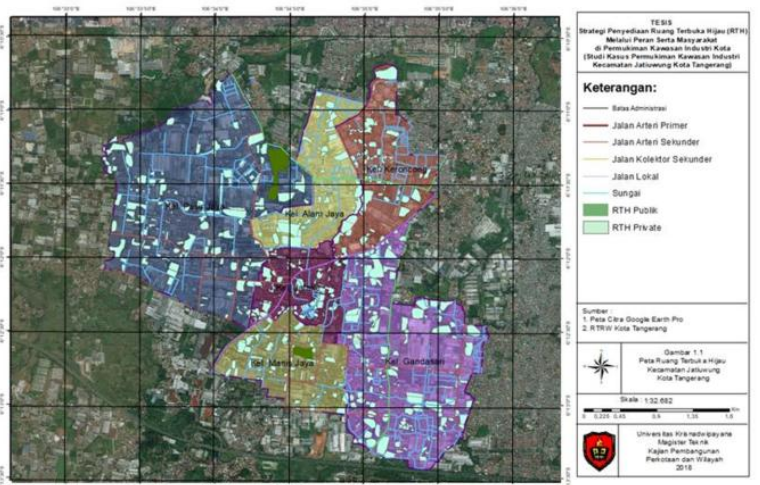

Gambar 3. Peta Sebaran RTH Publik dan Privat Kec. Jatiuwung

Total RTH eksisting $>30 \%$ sudah memenuhi ketentuan, tetapi proporsinya $29 \%$ RTH privat, $1 \%$ publik. Untuk jelasnya dapat dilihat pada tabel berikut ini.

Tabel 3. RTH Eksisting Kecamatan Jatiuwung

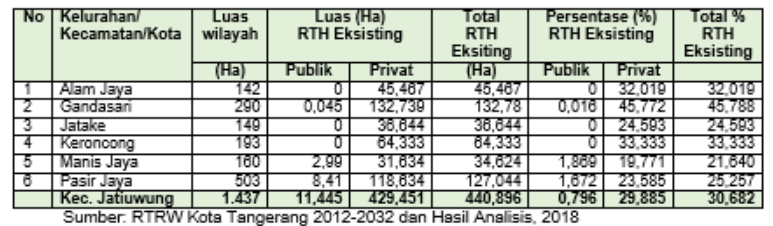

\section{Analisis Kebutuhan}

Kebutuhan RTH di Kec. Jatiuwung saat ini sudah terpenuhi. Proporsinya yang belum sesuai ketentuan $20 \%$ publik, $10 \%$ privat. Artinya bahwa pemerintah harus menyediakan lahan untuk RTH publikkarena RTH privat akan berkurang jika lahan industri dimanfaatkan secara optimal. 
Tabel 4. Kebutuhan RTH di Kecamatan Jatiuwung

\begin{tabular}{|c|c|c|c|c|c|c|c|}
\hline No. & Kelurahan/Kecamatan/Kota & $\begin{array}{l}\text { Luas } \\
\text { Wilaya }\end{array}$ & Kebu & $\begin{array}{l}\text { iomet) } \\
\text { umhan } \\
\text { un }\end{array}$ & Kebuas & an RTH & $\begin{array}{l}\text { Total } \\
\text { Luas } \\
\text { cHagas }\end{array}$ \\
\hline & & $(\mathrm{km} 2)$ & Publik & Private & Publik | & Private & \\
\hline & Aam Jaya & & & & 28,40 & 14,20 & $\begin{array}{ll}42,60 \\
42\end{array}$ \\
\hline & Gandasan & & 0,58 & 0.28 & 58,00 & 28,00 & 87,00 \\
\hline$\frac{0^{4}}{4}$ & $\begin{array}{l}\text { Jatake } \\
\text { Karoncong }\end{array}$ & $\frac{1.49}{1.93}$ & $\frac{0.298}{0.380}$ & $\frac{0.149}{0.193}$ & $\frac{20,80}{38,80}$ & $\frac{14,90}{19,30}$ & $\frac{44,70}{5.90}$ \\
\hline & $\begin{array}{l}\text { Merononge } \\
\text { Manis Jaya } \\
\end{array}$ & 1,80 & $\frac{0,360}{0,32}$ & $\frac{0,185}{0,18}$ & $\frac{38,600}{32,00}$ & $\frac{19,30}{18,00}$ & $\frac{5,7,00}{48,00}$ \\
\hline 8 & Pasir daya & $\frac{5.03}{4.37}$ & $\frac{1,000}{2874}$ & 0,503 & $\frac{100,80}{28700}$ & 50,30 & 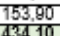 \\
\hline & $\begin{array}{l}\text { Kecamatan Jatuwun } \\
\text { Kota Tangerang }\end{array}$ & $\frac{14.37}{164.55}$ & $\frac{2,874}{32,910}$ & $\frac{1.437}{16,455}$ & $\frac{287,40}{3.291,00}$ & $\frac{143,70}{1.645,50}$ & \\
\hline
\end{tabular}

\section{Analisis Potensi RTH}

Penggunaan lahan di Kec. Jatiuwung di dominasi industri sebesar $88,46 \%$ dari total luas lahan di Kec. Jatiuwung, adapun penggunaan lahan untuk perumahan hanya $6,3 \%$, perdagangan dan jasa $0,49 \%$ dan penggunaan lainnya sebesar $4,74 \%$.

Berdasarkan penggunaan lahan tersebut di atas, maka potensi penyediaan RTH terbesar bukan di perumahan tetapi di industri.

Tabel 5. Potensi RTH di Kecamatan Jatiuwung menggunakan KDH Minimum 10\%

\begin{tabular}{|c|c|c|c|c|c|c|c|}
\hline \multirow{2}{*}{ No } & \multirow{2}{*}{$\begin{array}{l}\text { Kelurahan/Kecamatan } \\
\text { /Kota }\end{array}$} & $\begin{array}{l}\text { Luas } \\
\text { willygah }\end{array}$ & Perumahan & $\begin{array}{l}\text { Perdagangan } \\
\text { \& Jasa }\end{array}$ & Industri & Lain-lain & Total \\
\hline & & (HB) & (Ha) & (Ha) & (Ha) & (Ha) & (Ha) \\
\hline 1 & Alam Jaya & 142,00 & 0,80 & 0 & 12,57 & 0 & 13,37 \\
\hline 2 & Gandasari & 290,00 & 0,43 & 0 & 34,52 & 0 & 34,95 \\
\hline 3 & Jatake & 149,00 & 2,75 & 0,45 & 5,66 & 0 & 8,87 \\
\hline 4 & Keroncong & 193,00 & 2,64 & 0,25 & 12,97 & 0 & 15,86 \\
\hline 5 & Manis Jaya & 160,00 & 1,02 & 0 & 13,25 & 0 & 14,26 \\
\hline 6 & Pasir Jaya & 503,00 & 1,43 & 0 & 48,16 & 0 & 49,58 \\
\hline & Kecamatan Jatiuwung & 1437,00 & 9,06 & 0,71 & 127,12 & 6,81 & 143,70 \\
\hline
\end{tabular}

\section{Analisis Peranserta Masyarakat}

Hasil uji hipotesa menggunakan SPSS menunjukkan bahwa peranserta masyarakat belum optimal. Terdapat 4 faktor yang menyebabkan belum optimalnya penyediaan RTH. Untuk mengoptimalkannya menurut masyarakat yaitu:

1. Peranserta masyarakat dalam bentuk (fisik): penyediaan lahan untuk RTH dapat meningkatkan penyediaan RTH, lahan tersebut terbatas untuk menanam tanaman di pot, halaman terbuka, vertical garden atau roof garden hal ini disebabkan karena masyarakat tidak memiliki lahan.

2. Peranserta masyarakat dalam bentuk (ekonomi) : dana untuk penyediaan RTH, artinya masyarakat bersedia mengumpulkan dana untuk penyediaan RTH untuk membeli tanaman dan pot untuk peningkatan penyediaan RTH di rumahnya maupun dilingkungannya.

3. Peranserta masyarakat dalam bentuk (sosial) : tenaga untuk penyediaan RTH, artinya masyarakat bersedia bergotong royong untuk penyediaan RTH dirumahnya maupun di lingkungannya.

4. Peranserta masyarakat dalam bentuk kelembagaan(membuat kelompok, menyampaikan ide/gagasan) untuk penyediaan RTH, artinya bahwa masyarakat bersedia membuat kelompok ataupun menyampaikan ide/gagasannya dalam rangka meningkatkan penyediaan RTH.

D. Analisis Strategi Penyediaan RTH melalui Peningkatan Peranserta Masyarakat

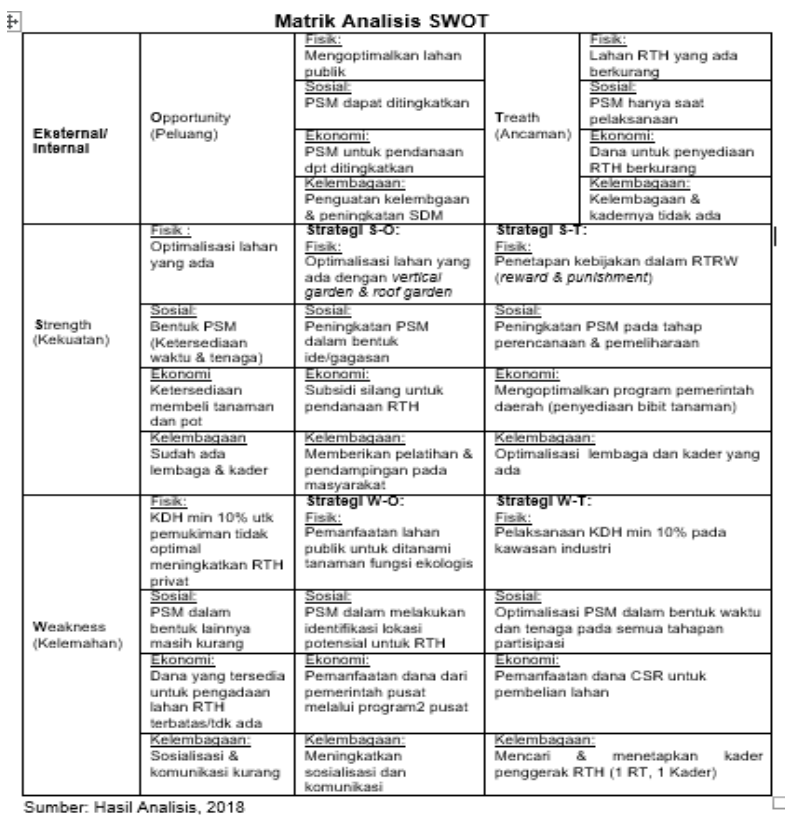

Hasil analisis diagram SWOT berada di kuadran 1 artinya progresif mendukung kebijakan pertumbuhan yang agresif (Growth oriented strategy), bahwa faktor-faktor yang ada (fisik, sosial, ekonomi dan kelembagaan) dapat meningkatkan peranserta masyarakat dalam penyediaan RTH di pemukiman kawasan industri kota. Untuk jelasnya dapat dilihat pada diagram berikut ini.

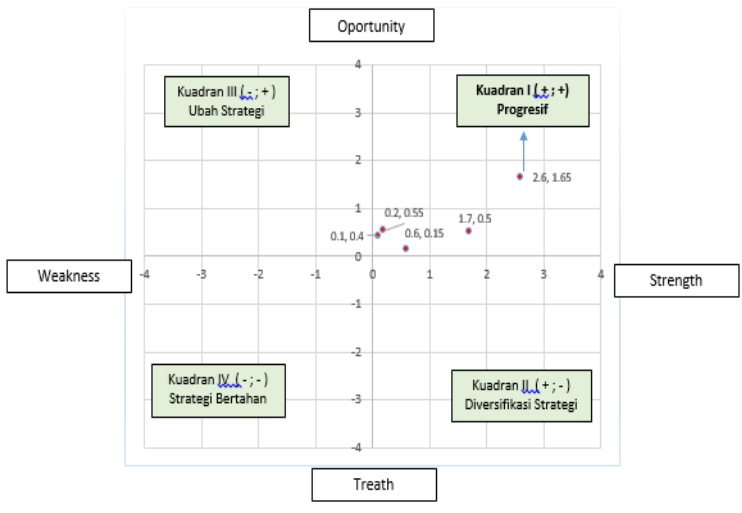

Diagram 3. Hasil SWOT 


\section{PENUTUP}

\section{Kesimpulan}

Hasil penelitian ini (1) membuktikan bahwa strategi sudah ada tetapi belum efektif disebabkan karena faktor fisik (ketersediaan lahan), faktor ekonomi (terbatasnya dana pemerintah), faktor sosial (peranserta masyarakat) dan kelembagaan (komunikasi dan sosialisasi); (2) membuktikan bahwa peranserta masyarakat belum optimal karena faktor fisik (lahan terbatas), faktor ekonomi (kesediaan masyarakat untuk penyediaan dana), faktor sosial (kesediaan masyarakat dalam bentuk tenaga dan pemikiran); faktor kelembagaan (kesediaan masyarakat membentuk kelompok); (3) kebutuhan RTH sudah terpenuhi, tetapi proporsinya belum sesuai, potensi terbesar penyediaan RTH adalah industri; (4) strategi peningkatan penyediaan RTH melalui peranserta masyarakat di pemukiman kawasan industri: (a) strategi pembangunan RTH dengan cara optimalisasi lahan pemukiman untuk penyediaan RTH dengan cara vertical garden dan roof garden; (b) sosialisasi, komunikasi, pendampingan, pelatihan, pemberian bibit pohon; (c) penyediaan dana untuk pelaksanaan program dan optimalisasi CSR (d) penguatan kelembagaan: penyampain usulan lewat musrenbang, menetapkan kader penggerak, pemeliharan dan pemantauan berbasis masyarakat.

\section{Saran}

1. Penelitian ini baru dilakukan di satu kecamatan dari beberapa kecamatan kawasan industri di Kota Tangerang, untuk menyempurnakannya perlu ada beberapa kecamatan yang berfungsi sebagai kawasan industri.

2. Analisis yang dilakukan baru secara umum, untuk memperoleh penelitian yang lebih rinci dan komprehensif maka perlu dilakukan penelitian secara mendalam terkait aspekaspek yang diteliti.

3. Penelitian ini dilakukan dalam waktu yang singkat, wilayah kajian hanya satu kecamatan dan dengan responden yang terbatas.

\section{DAFTAR PUSTAKA}

\section{Buku}

Adi, Isbandi Rukmanto, 2012, Intervensi Komunitas \& Pengembangan Masyarakat sebagai Upaya Pemberdayaan Masyarakat, PT Raja Grafindo Persada, Jakarta.

Departemen Pekerjaan Umum, Direktorat Jenderal Penataan Ruang, 2006. Ruang Terbuka Hijau Sebagai Unsur Utama Tata Ruang Kota, Jakarta.

Departemen Pekerjaan Umum, Direktorat Jenderal Penataan Ruang, 2008. Peraturan Menteri Pekerjaan Umum Nomor: 05/PRT/M/2008 tanggal 26 Mei 2008 tentang Pedoman Penyediaan dan Pemanfaatan Ruang Terbuka Hijau di Kawasan Perkotaan.

Mardikanto, Totok dan Poerwoko Soebianto, 2012, Pemberdayaan Masyarakat Dalam PerspektifKebijakan Publik, Afabeta, Bandung.

Pemerintah Republik Indonesia. Buku Pedoman Penyediaan dan Pemanfaatan Ruang Terbuka Hijau di Kawasan Perkotaan, Bab IV tentang Prosedur Perencanaan dan Peran Masyarakat.

Pemerintah Republik Indonesia, Undang-Undang Nomor 26 Tahun 2007 tentang Penataan Ruang.

Pemerintah Republik Indonesia, Undang-Undang Nomor 1 Tahun 2011 tentang Perumahan dan Permukiman.

Rustiadi, Ernan, Sunsun Saeful Hakim dan Dyah R. Panuju, 2011, Perencanaan dan Pengembangan Wilayah, Jakarta, Crestpent Press dan Yayasan Pustaka Obor Indonesia.

Saaty, Thomas L.(1980). "The Analytical Hierarchy Process. Planning, Priority Setting, Resource Allocation", McGraw-Hill, Inc., USA.

Sugandhy, Aca dan Rustam Hakim, 2007, Prinsip Dasar Kebijakan Pembangunan Berkelanjutan Berwawasan Lingkungan, Bumi Aksara.

\section{Jurnal}

Astriani, Nadia, Peran Serta Masyarakat Dalam Pengelolaan Ruang Terbuka Hijau (RTH) Di Kota Bandung.

Dewi R. Syahriyah, Nurhijrah, Saraswati Tedja, Dadang Hartabela, Saiful Anwar, 2015, Kualitas Ruang Terbuka pada Permukiman Industri di Kelurahan Cigondewah Kaler, Bandung, Jawa Barat, dalam prosiding temu ilmiah IPLBI 2015.

Febiandi, Rindi, 2012, Arahan Pengembangan Taman Purabaya sebagai Taman Kecamatan dan Taman PN Kertas sebagai Taman Kelurahan berdasarkan Persepsi dan Preferensi Masyarakat di Kecamatan 
Padalarang, (Tugas Akhir). Universitas Pasundan, Bandung.

Isfriana, Fatmi dan Iwan Kustiwan.Optimalisasi Penyediaan Ruang Terbuka Hijau Privat di Kota Cimahi, Dalam Jurnal Perencanaan Wilayah dan Kota B SAPPK V3N2.

Ismail, Yunita, Kebijakan Pembangunan Kawasan Industri yang Berwawasan Lingkungan (EcoIndustrial Park), Program Studi Manajemen, Fakultas Bisnis, President University.

Nurdiansyah, Ferlina, Aziz Nur Bambang, dan Hartuti Purnaweni, 2012, Strategi Peningkatan dan Penyediaan Ruang Terbuka Hijau Privat Rumah Tinggal Di Kawasan Perkotaan (Studi Kasus Di Kelurahan Panjunan, Kudus), Jurnal EKOSAINS/Vol.IV/No.3/November.

Pancawati, Juwarin, 2010. Analisis Kebutuhan Ruang Terbuka Hijau di Kota Tangerang, (Tesis). Sekolah Pascasarjana, Institut Pertanian Bogor. Bogor.

Rubianto, Eko Anton dan Ragil Haryanto, 2013, Bentuk Keterlibatan Masyarakat dalam Upaya Penghijauan pada Kawasan Hunian Padat di Kelurahan Serengan - Kota Surakarta, Jurnal Pembangunan Wilayah \& Kota UNDIP.

Situmorang, Rahel, Aidid A Gafar, Rissa Yuliana Dwi Jayanti, dkk, 2014, Studi Ruang Terbuka Kota Tangerang. [Laporan Penelitian]. Jakarta: Universitas Trisakti.

Sukarto, Haryono, 2006, Pemilihan Model Transportasi di DKI Jakarta dengan Analisis Kebijakan "Proses Hirarki Analitik", Jurnal Teknik Sipil, Universitas Pelita Harapan, Banten.

Susilowati, Indah, Nurini, 2013, Konsep Pengembangan Ruang Terbuka Hijau (RTH) pada Permukiman Kepadatan Tinggi, Jurnal Pembangunan Wilayah dan Kota UNDIP.

Sutanto, Agus. Strategi Penyediaan RTH di Perkotaan.

Tumada, La Ode Abdul Mirad, 2012, Analisis Strategis Pembangunan Kabupaten Muna. [Tesis]. Program Magister Perencanaan dan Kebijakan Publik, Universitas Indonesia, Jakarta.

Wahyudi. (2009). Ketersediaan Alokasi Ruang Terbuka Hijau Kota Pada Ordo Kota I Kabupaten Kudus. [Tesis]. Universitas Diponegoro, Semarang.

\section{Media Elektronik}

https://anisavitri.wordpress.com/2010/06/09/ruangterbuka-hijau-perkotaan-definisi-fungsicakupan-manfaatnya/

http://sappk.itb.ac.id/jpwk1/wpcontent/uploads/2015/12/V4N3 901-908.pdf. Diakses pada tanggal 29 Juli 2016 pukul 14.30 BBWI

http://sappk.itb.ac.id/jpwk1/wpcontent/uploads/2014/04/V1N2379-389.pdf. Diakses pada tanggal 29 Juli 2016 pukul $\underline{14.35 \mathrm{BBWI}}$ 